\title{
MAGYARORSZÁGON FŐTEVÉKENYSÉGKÉNT BAROMFI- ÉS SERTÉSÁGAZATTAL FOGLALKOZÓ VÁLLALKOZÁSOK PÉNZÜGYI HELYZETÉNEK VIZSGÁLATA
}

\author{
Gergely Andrea - Fenyves Veronika - Harangi-Rákos Mónika
}

\section{Összefoglalás}

Kutatásunk témája a magyarországi baromfi és sertéságazat gazdasági, azon belül is a pénzügyi helyzetének vizsgálata a 2005-2015 közötti idöszakban. Választásunk aktualitását a fogyasztási szerkezet átalakulása indokolja. Célunk egy részletes ágazati szintü elemzés készitése volt, mely hiánypótlónak tekinthetö, mivel a két ágazat átfogó gazdasági helyzetét leiró elemzések száma csekély. Kutatásunk a két ágazat termelési és fogyasztási adatainak áttekintésével kezdtük mind hazai, mind pedig nemzetközi szinten. Az elemzéseink alapjául szolgáló adatbázist az Agrárgazdasági Kutató Intézet biztositotta számunka. Az adatbázis a magyar baromfi és sertéságazat különbözö mérleg és eredménykimutatás adatait tartalmazza 2005 és 2015 között. A 2015. évi adatok a Standard Termelési Érték alapján kialakitott három méretkategória szerinti bontásban is rendelkezésünkre álltak. A kutatás elvégzése során a rendelkezésünkre álló számviteli beszámolók adatait vizsgáltuk mutatószámok segitségével. A mutatószámok között ok-okozati összefüggések kimutatását tüztük ki célul. Az eredményeink alapján megállapitható, hogy a két ágazat gazdasági helyzetének alakulása megegyezö képet mutat a nemzetközi termelési és fogyasztási trendekkel.

Kulcsszavak: Baromfiágazat, Sertéságazat, Pénzügyi helyzet elemzése, Pénzügyi helyzet összehasonlitása, Ágazati összehasonlitása

JEL: Q13, Q14, M41 
Gergely Andrea, Fenyves Veronika, Harangi-Rákos Mónika

\title{
ANALYSIS OF THE FINANCIAL SITUATION OF COMPANIES DEAL- ING WITH THE POULTRY AND PIG SECTOR AS A PRIMARY ACTIVI- TY IN HUNGARY
}

\begin{abstract}
The subject of our research is the examination of the economic and financial situation of the Hungarian poultry and pig sector in the period between 2005 and 2015. The actuality of our choice is justified by the transformation of the consumption structure. Our objective was to carry out a detailed sector-level analysis, which might fill a research gap as the number of analyzes describing the overall economic situation of the two sectors is small. We started our research by reviewing the production and consumption data of the two sectors at both domestic and international level. The database on which our analyzes are based was provided by the Research Institute for Agricultural Economics. The database contains various balance sheet and profit and loss account data of the Hungarian poultry and pig sector from 2005 to 2015. Figures concerning 2015 were also available in three size categories based on the Standard Production Value. In the course of the research, the data of the available annual statements were examined by means of index numbers. We aimed to detect cause and effect relationships among the indicators. Based on our findings, it can be concluded that the economic situation of the two sectors shows a picture, which is identical to the international production and consumption trends.
\end{abstract}

Keywords: poultry sector, pig sector, analysis of the financial situation, comparison of the financial situation, sectoral comparison

JEL: Q13, Q14, M41 
Magyarországon főtevékenységként baromfi- és sertéságazattal foglalkozó vállalkozások... 43

\section{Bevezetés}

Az emberiség táplálkozásában a húsfogyasztás a kezdetektől kiemelkedő szerepet tölt be. A hús tehát egy alapvető emberi élelmiszer (Szücs et al., 2017). Az élelmiszerfogyasztás szerkezete folyamatosan változik, hiszen a gazdasági fejlődés hatására megnövekedett háztartási jövedelmeknek köszönhetően egyre nagyobb mértékű a magasabb hozzáadott értékü élelmiszerek - leginkább a hús és a tejtermékek - fogyasztása (Popp et al., 2017). A húsfogyasztás és a hústermelés tekintetében világszinten, az Európai Unió területén és hazánkban is a két legmeghatározóbb szakágazat a sertésés a baromfiipar. Világszinten nem elhanyagolható természetesen a marha, a juh, illetve a hal fogyasztása sem, azonban a sertés és a baromfihús fogyasztása és termelése kiemelkedő és meghatározó szereppel bír. A két iparág között az utóbbi időben kialakult egyfajta verseny. A korábbi évtizedekben a sertéshús termelése jóval megelőzte a baromfihúsét, azonban az utóbbi 20 évben a baromfiipar elkezdte ledolgozni ezt a hátrányt, és a legfrissebb kutatások és előrejelzések szerint át fogja venni a vezetést a termelés, a fogyasztás és a jövedelmezőség tekintetében is. Jelen kutatásunk célja tehát az, hogy a baromfi és a sertéságazat gazdasági helyzetének alakulását megvizsgáljuk és összehasonlítsuk egymással. A téma aktualitását a jelenleg zajló termelési és fogyasztási tendenciák átalakulása indokolja.

\section{Anyag és módszer}

\section{A baromfi és a sertéságazat vizsgálata}

Kutatásunk a két ágazat hazai és nemzetközi termelési és fogyasztási adatainak áttekintésével kezdtük, amely alátámasztotta azt, hogy miért érdemes ennek a két ágazatnak az elemzésével foglalkozni. A témával foglalkozó több kutató is megállapította az előző évek tendenciáit figyelembe véve, hogy a baromfihús termelése meg fogja haladni a sertéshús termelését. Popp József 2014-es publikációjában azt jósolta, hogy a 2020-as évek elején fog bekövetkezni ez a változás. A FAO legfrissebb adatai szerint 2016-ban a baromfihús termelése már meghaladta a sertéshús termelését, illetve a további előrejelzéseket tekintve ez a tendencia a következő években is megmarad, ahogyan az az 1 . ábrán is látszik. 


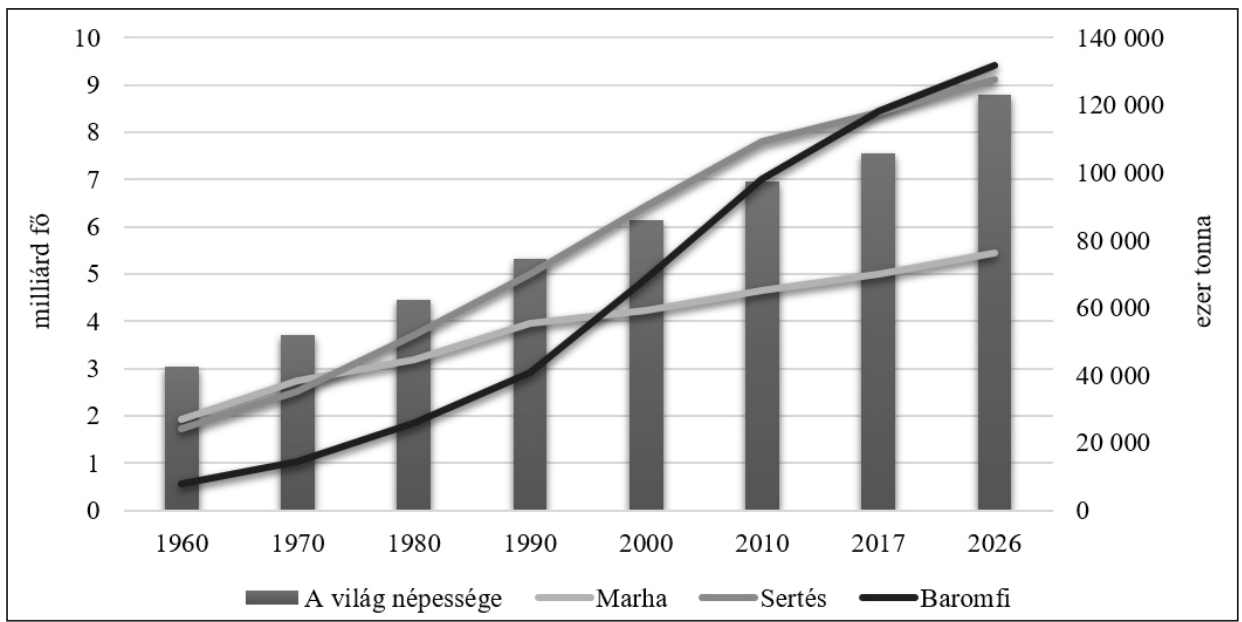

1. ábra: A világ népességének és hústermelésének alakulása

Forrás: Saját szerkesztés, OECD-FAO (2017-2026) alapján

Ezen adatok fényében a következőben a baromfi és sertéságazat termelési és fogyasztási adatainak alakulására koncentráltunk.

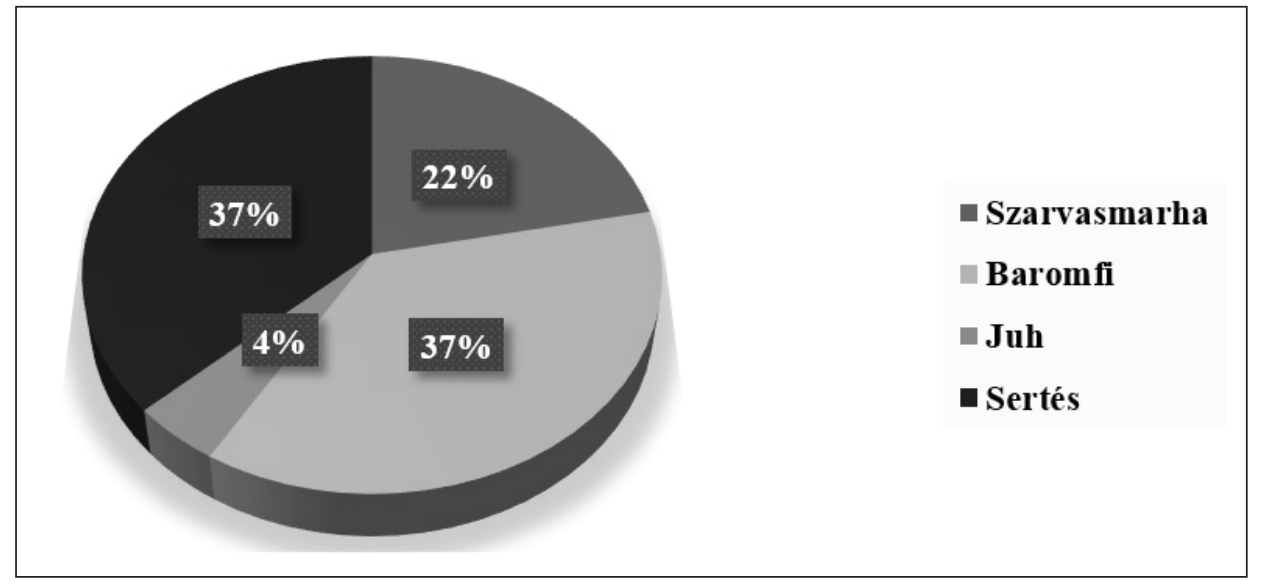

2. ábra: A világ hústermelésének százalékos megoszlása

Forrás: Saját szerkesztés, OECD-FAO (2018) alapján

A világ összes hústermelésének megoszlását tekintve megállapítható, hogy a baromfi és a sertéshús termelése a legjelentősebb, ez a két ágazat adja a világ össze hústermelésének 74\%-át, fele-fele arányban. Míg 2011-ben ugyanezen adatok vizsgálatakor a mérleg nyelve még a sertéshús termelés felé dőlt, mára teljesen megegyezik. A 
Magyarországon főtevékenységként baromfi- és sertéságazattal foglalkozó vállalkozások... 45

szarvasmarha ágazat a globális hústermelésből csupán 22\%-kal részesedik, a juhhús termelés pedig kevesebb, mint 4\%-a az összes hústermelésnek (OECD-FAO, 2018). A hústermelést követően az összes húsfogyasztás megoszlását is megvizsgáltuk. Az összes húsfogyasztás megoszlásának kiszámítása során ugyanezeket a százalékos arányokat kaptuk, amelyből arra következtethetünk, hogy a termelés nagyon szoros kapcsolatban van a fogyasztással.

Ezt követően pedig a két ágazat hazai helyzetének vizsgálatával folyatattuk kutatásunk.

\begin{tabular}{|c|c|c|c|c|c|c|}
\hline \multirow{2}{*}{ Év } & \multirow{2}{*}{ Termelés } & \multirow{2}{*}{ Behozatal } & \multirow{2}{*}{ Kivitel } & \multirow{2}{*}{ Belföldi felhasználás } & \multicolumn{2}{|c|}{ Hazai fogyasztás } \\
\cline { 5 - 8 } & & \multicolumn{7}{|c|}{ ezer tonna } \\
\hline $\mathbf{1 9 7 0}$ & 208 & 0 & 55 & 147 & 147 & kgs \\
\hline $\mathbf{1 9 7 5}$ & 263 & 0 & 106 & 161 & 161 & 15 \\
\hline $\mathbf{1 9 8 0}$ & 341 & 1 & 133 & 194 & 193 & 18 \\
\hline $\mathbf{1 9 8 5}$ & 391 & - & 167 & 221 & 221 & 21 \\
\hline $\mathbf{1 9 9 0}$ & 434 & 6 & 184 & 236 & 236 & 23 \\
\hline $\mathbf{1 9 9 5}$ & 374 & 0,3 & 106 & 247 & 247 & 24 \\
\hline $\mathbf{2 0 0 0}$ & 458 & 21 & 125 & 344 & 344 & 34 \\
\hline $\mathbf{2 0 0 5}$ & 374 & 41 & 112 & 301 & 301 & 30 \\
\hline $\mathbf{2 0 1 0}$ & 375 & 38 & 158 & 245 & 245 & 25 \\
\hline $\mathbf{2 0 1 5}$ & 490 & 39 & 229 & 283 & 283 & 29 \\
\hline
\end{tabular}

1. táblázat: A magyarországi baromfihús-mérleg alakulása 1970-2015 között Forrás: Saját szerkesztés, KSH (2018) alapján

A magyar baromfihús-termelés a vizsgált időszakban szintén elég nagy ingadozásokat mutat. A legfrissebb rendelkezésre álló KSH adatok szerint 2015-ben hazánk 490 ezer tonna baromfihúst termelt, melyből 229 ezer tonna exportálásra került. A behozatalunk ehhez képest csekély. 1970 óta az egy före jutó baromfihús-fogyasztás a duplájára nőtt, 2015-ben közel 30 kg/fö volt. Hazánk húsiparának egyik fö erőssége az exportra termelés, mely kifejezetten igaz a baromfihús esetében. Alátámasztja ezt az a körülmény is, hogy 2010 és 2015 között a baromfiexportunk több, mint 70 ezer tonnával nőtt, ledolgozva ezzel a korábbi évek visszaesését. A hazai baromfihús export túlnyomó többségét a csirke- és pulykahús exportja adja (KSH, 2018).

A magyar mezőgazdaság fontos területe a baromfitartás, 2015-ben a bruttó kibocsátásból 13\%-kal részesedett, így az állattenyésztésen belül a legnagyobb arányt képviseli. A baromfiágazaton belül is a tyúkfélék és a tojástermelés a legmeghatározóbbak, hiszen az állatállomány 80\%-át teszik ki. A baromfitartás költségeinek közel 60\%-át a takarmányköltségek teszik ki. Ezzel szemben az ágazat alacsony munka- 
erőköltséggel bír, ami 2015-ben átlagosan csupán a költségek 8\%-át tette ki (AKI, 2017).

\begin{tabular}{|c|c|c|c|c|c|c|}
\hline \multirow{2}{*}{ Év } & \multirow{2}{*}{ Termelés } & \multirow{2}{*}{ Behozatal } & \multirow{2}{*}{ Kivitel } & \multirow{2}{*}{ Belföldi felhasználás } & \multicolumn{2}{|c|}{ Hazai fogyasztás } \\
\cline { 5 - 7 } & & & & \multicolumn{6}{|c|}{ ësszesen } & egy fóre \\
\hline $\mathbf{1 9 7 0}$ & 312 & 29 & 29 & 307 & 307 & kg \\
\hline $\mathbf{1 9 7 5}$ & 501 & 2 & 63 & 436 & 436 & 41 \\
\hline $\mathbf{1 9 8 0}$ & 564 & 4 & 127 & 431 & 431 & 40 \\
\hline $\mathbf{1 9 8 5}$ & 628 & 1 & 167 & 456 & 456 & 43 \\
\hline $\mathbf{1 9 9 0}$ & 616 & 3 & 197 & 402 & 402 & 39 \\
\hline $\mathbf{1 9 9 5}$ & 333 & 19 & 73 & 280 & 280 & 27 \\
\hline $\mathbf{2 0 0 0}$ & 397 & 27 & 131 & 286 & 286 & 28 \\
\hline $\mathbf{2 0 0 5}$ & 290 & 89 & 103 & 270 & 270 & 27 \\
\hline $\mathbf{2 0 1 0}$ & 301 & 136 & 174 & 253 & 253 & 25 \\
\hline $\mathbf{2 0 1 5}$ & 303 & 144 & 164 & 271 & 271 & 28 \\
\hline
\end{tabular}

2. táblázat: A magyarországi sertéshús mérleg alakulása 1970 és 2015 között

Forrás: Saját szerkesztés KSH (2018) alapján

Magyarország sertéshústermelése a vizsgált időszakban ingadozást mutat, azonban az utóbbi tíz évben lassú ütemű növekvő tendencia volt jellemző. A behozatalunk a 2000-es évet követően ugrásszerűen megnőtt, annak ellenére, hogy a fogyasztásunk az 1990-es évektől kezdődően napjainkra 130 ezer tonnával esett vissza. A hazai sertéshús exportja mennyiségben kevesebb, mint az import, ugyanakkor értékben kifejezve az export mégis erősebb, mint a behozatal. A legtöbb sertéshúst Romániába, Japánba, Kínába és Olaszországba szállítjuk. A sertéshús behozatalunk több, mint 60\%-a Németországból, Spanyolországból, Lengyelországból és Ausztriából származik. Összességében tehát Magyarország élősertés és sertéshús tekintetében nettő importőr (KSH, 2018).

Fontos megemlíteni, hogy a sertéshús egy före eső fogyasztása az 1980-as évek végéhez képest $15 \mathrm{~kg}$-mal esett vissza. Hazánkban az állattenyésztés egyik tradicionális ágazata a sertéstartás, amely az utóbbi 5-10 évben a szarvasmarha ágazathoz hasonlóan komoly gondokkal küszködött. A két ágazat problémája eltérő, hiszen a sertéságazat hullámzó és időszakonként jelentkező jövedelemhiányban szenved, ellentétben a szarvasmarha ágazattal, ahol a probléma tartósan jelen van. A sertéságazat problémája abból fakad, hogy a rendkívül gyorsan változó piaci körülményekre nem tud elég hamar reagálni és alkalmazkodni azokhoz (AKI, 2017).

A fent elemzéseink alapján tehát arra jutottunk, hogy a magyarországi baromfi és sertéságazat gazdasági helyzetének vizsgálatát végezzük el mutatószámok alkalmazásával. 
Magyarországon fötevékenységként baromfi- és sertéságazattal foglalkozó vállalkozások... 47

\section{Az átfogó gazdasági elemzés szükségessége és jelentösége}

A vállalkozások megítélésének és értékelésének egyik alapvető módszere az elemzés. Az elemzés valójában az összefüggések és a gazdasági jelenségek valamint az ezekre ható tényezők vizsgálatát és feltárását jelenti. A gazdasági elemzés tárgya és célja sokféle lehet. A beszámoló elemzéséhez olyan módszerek tartoznak, amelyek föként a mérleg és az eredménykimutatás adatait felhasználva nyújtanak segítséget a vállalkozások gazdálkodásának megismerésében és az összefüggések feltárásában (Bán et al., 2017).

A beszámoló összefoglaló jellegéből fakadóan a benne lévő adatok elemzésben történő felhasználás is átfogóan értékeli a gazdálkodó szervezeteket. A beszámolóval kapcsolatban egy vállalkozás elemzése általában kiterjed a vagyoni és a pénzügyi helyzet alakulására, valamint a gazdálkodás jövedelmezőségének vizsgálatára (Bíró et al., 2016).

Az elemző célú kutatások során a vizsgált jelenségeket legtöbbször mutatószámok segítségével fejezzük ki. Ebből fakad, hogy sok esetben a pénzügyi elemzés során alkalmazott mutatószámképzést hagyományosan mérlegelemzésként fogják fel. A mutatószámok olyan nagymértékben összevont, tömörített numerikus kifejezések, amelyek koncentráltan adnak felhasználható ismeretet számszerüsíthető jelenségekről. A mutatószámok segítségével a beszámoló kevés, de jól értelmezhető jellemzőkké vonható össze, azzal a céllal, hogy egyszerű módon leképezhető legyen és ezzel egy időben gyors és értékelhető áttekintést adjon a vállalkozás gazdasági helyzetéről (Bíró et al., 2016).

A mutatószámok olyan jelentősen összevont számértékek, amelyek a vállalati jelenségeket koncentrált formában fejezik ki. A mutatószámok tömören fejezik ki a vizsgált eseményt, egyszerüek, áttekinthetőek és megkönnyítik az összehasonlításokat. A mutatószámokat széleskörüen lehet alkalmazni, a mutatószámok: a tervezés, döntéselőkészítés, irányítás és ellenőrzés segédeszközei minden hierarchikus szinten, a belső és a külső vállalati elemzés eszközei, minden hierarchikus szint információs rendszerének részei (Musinkszki, 2014).

A vállalkozások pénzügyi helyzetének vizsgálatát a mérleg, az eredménykimutatás és a sok esetben fontos információkat tartalmazó kiegészítő melléklet és cash-flow kimutatás adatainak felhasználásával végezhetjük el. A mérleg adatainak felhasználásával likviditási mutatókat számolhatunk, amelyek a vállalkozások pénzügyi stabilitását tükrözik, mivel azt mutatják meg, hogy az esedékes kötelezettségeknek mennyire tudnak eleget tenni. A likviditási helyzet elemzése alatt a likvid eszközöknek és a rövid lejáratú kötelezettségeknek az összehasonlítását értjük (Siklósi-Veress, 2011). A vállalat likviditását többféle szempont szerint is értelmezhetjük. Leggyakrabban a pillanatnyi fizetőképességet és a vállalat eszközeinek eladhatóságát értjük alatta (Havran, 2010). Egy 2012-es cikk rávilágít arra, hogy a kettős könyvvitelt vezető vál- 
lalkozások által kötelezően elkészítendő éves pénzügyi kimutatások, azaz számviteli beszámolók olyan információbázist jelentenek, amelyek segítséget nyújthatnak egyrészről a vállalati likviditásmenedzsment támogatásához, másrészről a vállalkozások likviditási helyzetének megítéléséhez (Kovács-Mohl, 2012).

\section{Az elemzett adatbázis bemutatása}

A két ágazat mélyebb és pontosabb elemzéséhez, szükségünk volt erre alkalmas speciális adatokra. Ezen adatok elérését az Agrárgazdasági Kutató Intézet egyik munkatársa biztosította számunkra, lehetővé téve így a kutatásunk elkészítését és egy olyan elemzés elvégzését, amelyhez hasonlót korábban még nem készítettek. Az így már meglévő adatok alapján a két ágazat gazdasági elemzését végeztük el, ugyanis a gazdasági elemzés célja és feladata, hogy a rendelkezésünkre álló adatok feldolgozásra kerüljenek, és az ezekből a tudomásunkra jutó információkat felhasználva növelni tudjuk az eredményesebb és hatékonyabb gazdálkodást (Bán et al., 2016).

\section{Eredmények}

\section{A likviditás vizsgálata}

A vizsgálatainkat a két ágazat értékesítéséből származó nettó árbevételek alakulásának áttekintésével kezdtük.

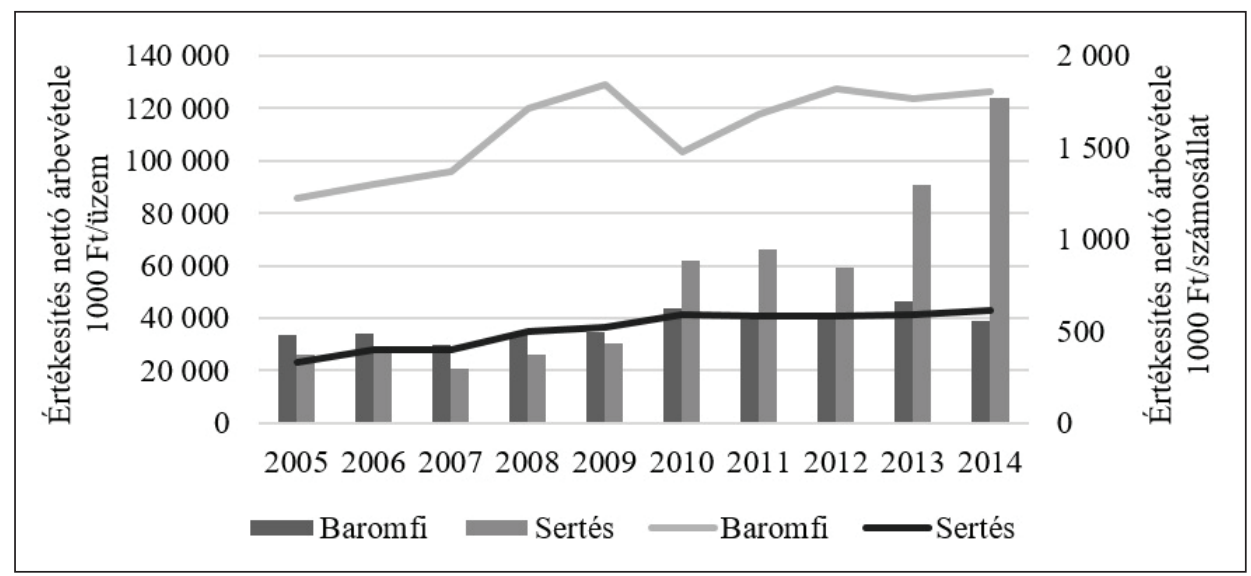

3. ábra: A hazai baromfi- és sertéstartók értékesítés nettó árbevételeinek alakulása különböző egységre vetítve 2005 és 2014 között Forrás: Saját szerkesztés, AKI (2018) alapján 
Magyarországon fötevékenységként baromfi- és sertéságazattal foglalkozó vállalkozások... 49

Az adatbázisban, ahogyan a 3. ábrán is látszik, az ágazatok árbevétel adatait nem csupán $1000 \mathrm{Ft} /$ számosállatban kifejezve kaptuk meg, hanem $1000 \mathrm{Ft} /$ üzem mértékegységben kifejezve is. A 18. ábrát elemezve láthatjuk, hogy mindkét ágazat árbevétele a kisebb ingadozásoktól eltekintve 2005 és 2014 között növekvő trendet mutat, ami egyértelmüen pozitív. Ahogy alaposabban megvizsgáltuk a 18. ábrát, észrevettem, hogyha az értékesítés árbevétele $1000 \mathrm{Ft} /$ számosállatban van kifejezve, akkor ez alapján a baromfiágazat jobban teljesít. Azonban ha az árbevételi adatok 1000 Ft/üzem mértékegységben vannak kifejezve, akkor egyértelmű, hogy a sertéságazat teljesítménye kedvezőbb.

Ezután természetesen a 2015-ös árbevételi adatokat is megvizsgáltuk méretkategóriák szerinti bontásban is mindkét ágazat esetében.

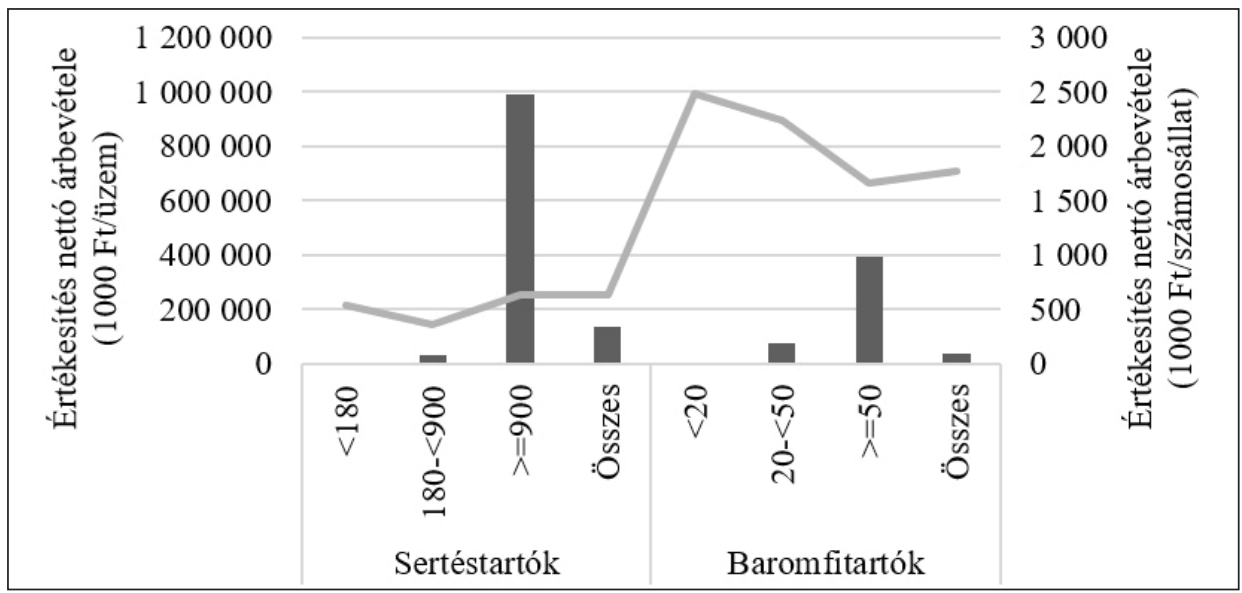

4. ábra: A hazai baromfi- és sertéstartók értékesítés nettó árbevételeinek alakulása különböző méretkategóriák szerint 2015-ben

Forrás: Saját szerkesztés, AKI (2018) alapján

A 4. ábráról látszik, hogy mindkét ágazatban a legnagyobb méretkategóriába sorolható vállalatok árbevételeinek értékei a legmagasabbak 1000 Ft/üzem mértékegységben kifejezve. Viszont ha az árbevételi adatok $1000 \mathrm{Ft} /$ számosállat mértékegységben vannak kifejezve, akkor mindkét ágazatban a legkisebb méretkategóriába sorolható vállalatok árbevétel adatai kiemelkedően magasak. Ugyan a sertéságazatban a legkisebb méretbe tartozó vállalatok nem előzik meg a legnagyobb méretű vállalatokat, azonban kevéssel maradnak le tőlük.

A likviditási mutatók a vállalkozás azon képességét mérik, hogy hogyan képes a rövid távú kötelezettségeinek eleget tenni. A mutató a vállalat likvid eszközeit hasonlítja a rövid távú kötelezettségeihez. A mutató magasabb értéke azt jelzi, hogy a vállalkozás várhatóan időben eleget tud tenni rövid távú kötelezettségeinek és finan- 
szírozni képes a közeli jövőben a működési költségeit. Az alacsonyabb mutatóérték azt jelezheti, hogy a vállalkozásnak nehézségei lehetnek a rövid távú kötelezettségei teljesítésében, ami problémát okozhat a cég müködésében is (Fenyves et al., 2016).

Az általános likviditási mutató értéke azt jelzi, hogy a mobilizálható, könnyen pénzzé tehető eszközök a likvid - rövid időn belül kiegyenlítendő - tartozások hány százalékát teszik ki. A mutató értéke minél magasabb, annál biztonságosabbnak tekinthető a vállalat likviditása. A mutató 1 -nél kisebb értéke esetén fennáll a vállalkozás fizetésképtelenségének közvetlen veszélye, 1 fölötti értéke elfogadható, a normális üzemmenet esetén az 1,2-1,8 körüli érték tekinthető megfelelőnek, a túl magas érték azonban a jövedelmezőség romlását vonhatja maga után (Éva, 2007). Mind a baromfi-, mind pedig a sertéságazat általános likviditási mutató értékei kedvezően alakultak 2005 és 2014 között. A sertéstartók esetében az időszak elején a mutató értéke közel 2,5 volt, de az időszak végére 1,7-re csökkent, ami a szektor normál müködését jelzi.

A likviditási gyorsráta, vagy más néven a gyors likviditási mutató a készletek állományát figyelmen kívül hagyja, mivel a vállalkozás olyan immobil készletekkel is rendelkezik, amelyek nem tehetőek gyorsan pénzzé. A készletek a leglassabban tehetőek pénzzé, az ő értékesítésük a legkockázatosabb, ezért jó vele korrigálni a likviditási mutatót. Ha benne van a mutatóban, akkor felfelé torzít, ha korrigálunk vele, akkor reálisabb képet kapunk a vállalkozásról. A kapott értékek közül az 1 vagy ennél magasabb értéket tekintik megfelelőnek (Brealey-Myers, 2011). A baromfitartók gyors likviditási rátájának alakulása stabilabbnak és kiegyensúlyozottabbnak tekinthető, míg a sertéstartók esetében ennek a rátának az értéke nagyobb ingadozásokat mutat.

Az összes eladósodottsági mutató azt mutatja meg, hogy a vállalat milyen mértékben finanszírozza eszközeit idegen tőkével, így arra is tudunk következtetni, hogy mennyire tőkeerős egy vállalat, esetünkben az ágazat (Brealey-Myers, 2011). A baromfiágazat eladósodottsági mutatói a vizsgált időszak kezdetén megközelítették az 50\%-ot, ami azt jelenti, hogy az ágazatban tevékenykedő vállalatok saját tőkéből csupán az eszközeik felét tudták finanszírozni. 2014-re a mutató értéke stabilizálódni látszik, hiszen kb. 10\%-kal csökkent. A sertéságazati eladósodottság kedvezőnek tekinthető, mivel 2005 és 2014 között a mutató legnagyobb értéke 40\% volt, ami nem kritikus érték, illetve többször volt 30\% alatt is. Ezen megállapításainkat a 16. ábrán szemléltettük. 


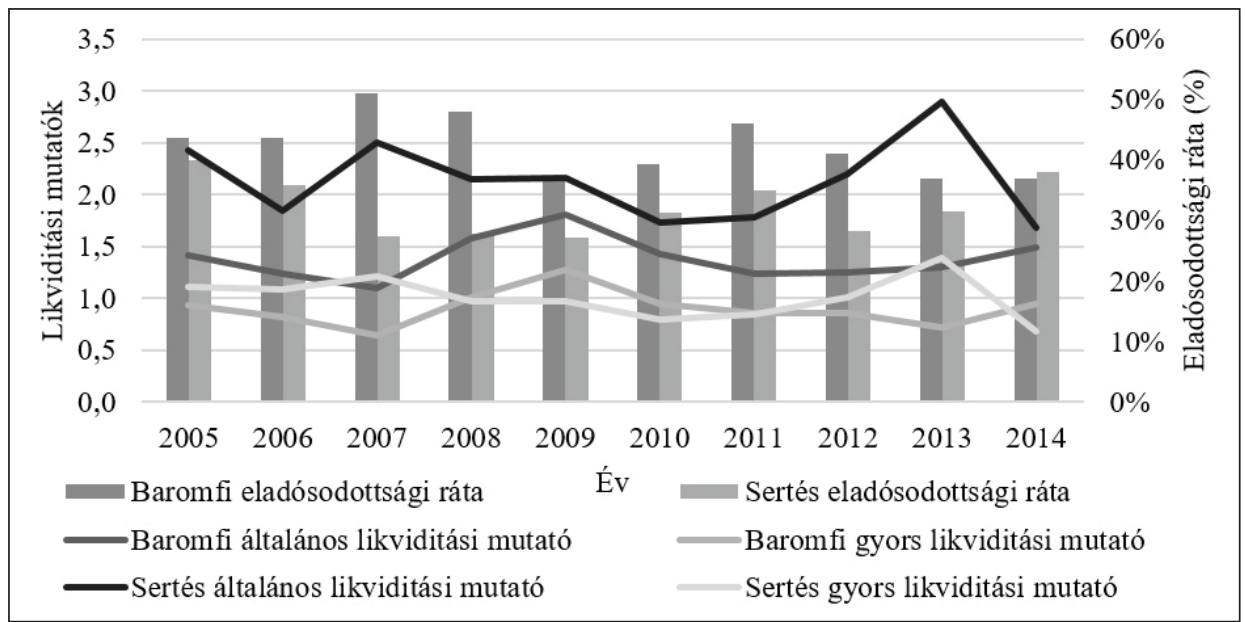

\section{5. ábra: A hazai baromfi- és sertéstartók likviditási mutatóinak és eladósodottsági}

\section{rátájának alakulása 2005 és 2014 között}

Forrás: Saját szerkesztés, AKI (2018) alapján

2015-ben az ágazatok likviditási mutatói összesítve mindkét esetben jónak tekinthetőek, azonban a sertéstartók legkisebb és középső méretkategóriájába tartozó vállalatok likviditása igen magas. Alapvetően az nem probléma, ha egy vállalat fizetőképessége magas, azonban meg kell vizsgálni, hogy ez minek köszönhető. Mivel a likviditási mutatók képlete a forgóeszközök és a rövid lejáratú kötelezettségek hányadosából képződik így az eltérések és a változások e mérlegtételek változásában keresendők.

Ez esetben a magas likviditási értékek a magas forgóeszköz állománynak, ezen belül is a követelések, az értékpapírok és a pénzeszközök összértéke magas arányának köszönhető. Az adatbázisból sajnos nem derül ki, hogy a három érték közül pontosan melyik a legnagyobb arányú. Ugyanezen méretkategóriáknál a baromfitartók esetében is enyhén magasabb a mutatók értéke, azonban itt nem tekinthető kritikusan kiugró értékeknek. 


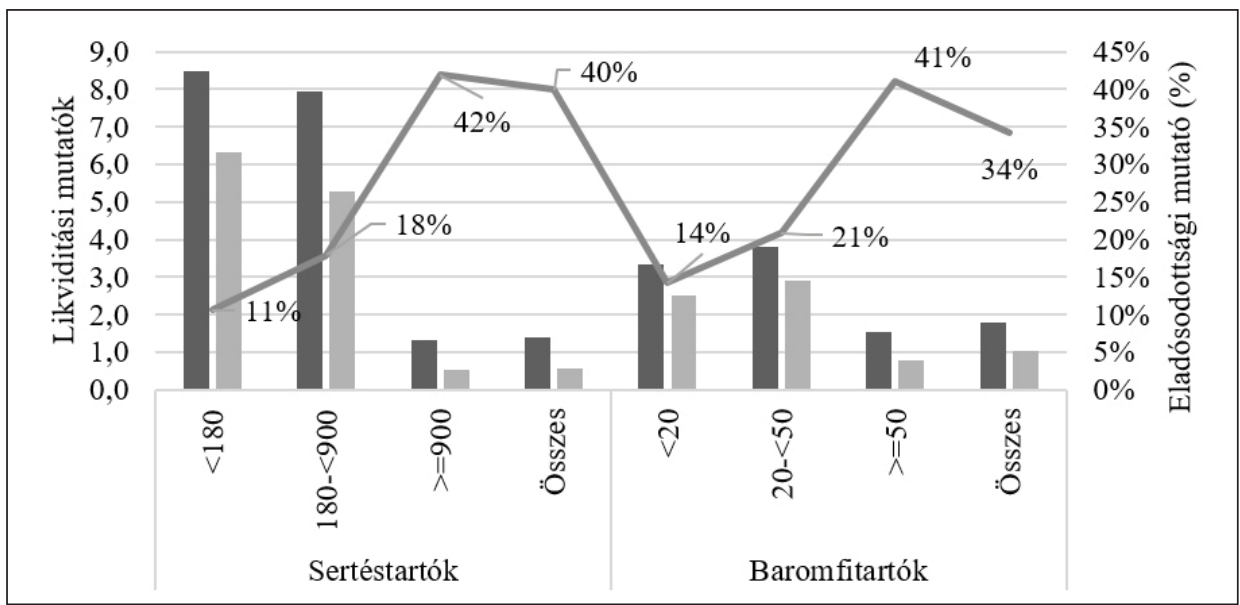

\section{6. ábra: A hazai baromfi és sertéstartók likviditási mutatóinak és eladósodottsági rátájának különböző méretkategóriák szerinti alakulása 2015-ben \\ Forrás: Saját szerkesztés, AKI (2018) alapján}

Természetesen az iparági sajátosságoknak is megvannak a saját torzító hatásai. A téma tehát további kutatási lehetőségeket is rejt magában, azonban a mutatók rávilágítottak arra, hogy a termelési és fogyasztási trendek változása kimutatható hatást gyakorol a két ágazat gazdasági helyzetére, mely egyértelmüen megmutatkozik a likviditási helyzetükben is.

\section{Következtetések, javaslatok}

Kutatásunkban a hazai baromfi és sertéságazat likviditási helyzetének vizsgálatára koncentráltunk. Célunk az volt, hogy megvizsgáljuk, milyen hatást gyakorol a termelési és fogyasztási szerkezetváltás a két ágazat fizetőképességi helyzetére. Ennek érdekében elsősorban a két ágazat különböző termelési és fogyasztási adatainak alakulását vizsgáltuk meg, melyből egyértelmüen látszik, hogy a baromfihús termelés jelentősége az utóbbi években megnőtt. Arra voltunk kíváncsiak, hogy ennek a szerkezetváltás milyen hatást gyakorol az ágazatok gazdasági helyzetére. Míg az árbevételeik alakulásából nem tudtunk egyértelmű következtetést levonni, addig a likviditási mutatók már egy egyértelműbb képet festettek az ágazatok helyzetéről. Ezek alapján elmondhatjuk tehát, hogy a szerkezetváltás kimutatható hatással van a két ágazatra. 
Magyarországon főtevékenységként baromfi- és sertéságazattal foglalkozó vállalkozások... 53

\section{Hivatkozott források}

[1.] Agrárgazdasági Kutató Intézet (2017): Agrárpiaci jelentés, Baromfi. XVII. évfolyam, 22. szám. 1-20. o.

[2.] Agrárgazdasági Kutató Intézet (2017): A főbb mezőgazdasági ágazatok költség- és jövedelemhelyzete 2013-2015. 38-44 o.

[3.] Bán E. - Kresalek P. - Pucsek J. (2017): A vállalati gazdálkodás elemzése. Perfekt Gazdasági Tanácsadó, Oktató és Kiadó Zrt., Budapest, 526 o.

[4.] Bíró T. - Kresalek P. - Pucsek J. - Sztanó I. (2016): A vállalkozások tevékenységének komplex elemzése. Perfekt Gazdasági Tanácsadó, Oktató és Kiadó Zrt., Budapest, 11-53. o.

[5.] Brealey A. R. - Myers S. C. (2011): Modern Vállalati Pénzügyek. Panem Kiadó, Budapest, 772-905. o.

[6.] Éva K. (2007): Számvitel elemzés I. Perfekt Gazdasági Tanácsadó, Oktató és Kiadó

[7.] FAO (2018): http://www.fao.org/faostat/en/\#data/OA Letöltés dátuma: 2018. 05. 10.

[8.] Fenyves V. - Bács Z. - Tarnóczi T. (2016): A forgótőke menedzsment jelentősége a vezetői döntésekbe. http://acta.bibl.u-szeged.hu/54937/1/ taylor_2016_001_037-045.pdf Letöltés dátuma: 2018. 10. 01.

[9.] Havran D. (2010): A vállalati likviditáskezelés. PhD-értekezés. Budapesti Corvinus Egyetem. http://phd.lib.uni-corvinus.hu/535/1/havran_daniel. pdf Letöltés dátuma: 2018.10.01.

[10.] KSH (2018): 4.1.2.1.7. Baromfihúsmérleg tábla. http://www.ksh.hu/docs/ hun/xstadat/xstadat_hosszu/elm07.html Letöltés dátuma: 2018. 06. 12.

[11.] KSH (2018): 4.1.2.1.1. Sertéshúsmérleg tábla. http://www.ksh.hu/docs/ hun/xstadat/xstadat_hosszu/elm01.html Letöltés dátuma: 2018. 06. 12.

[12.] Kovács D. - Mohl G. (2012): A vállalati likviditásmenedzsment számviteli támogatása. Vezetéstudomány XLIII. évf. 2012. 10. szám 19-35. o.

[13.] Musinszki Z. (2014): Mit mutat a mérleg? A hányadoselemzés alapjai és buktatói II Controller Info II. évfolyam ISSN 20639309 2014/1 42-53. o.

[14.] OECD-FAO (2018): Compare countries. http://www.agri-outlook.org/ data/ Letöltés dátuma: 2018. 05. 15. 
[15.] OECD-FAO (2018): Agricultural Outlook 2017-2026. https://stats.oecd. org/viewhtml.aspx?datasetcode=HIGH_AGLINK_2017\&lang=en\# Letöltés dátuma: 2018. 05. 15.

[16.] Popp J. (2014): A baromfiágazat globális helyzete és kilátásai (II.). Baromfiágazat. 14. évf. 1. sz. 4-11. p.

[17.] Popp J. - Oláh J. - Szenderák J. - Harangi-Rákosi M. (2017): A marhahús előállítás nemzetközi és hazai piaci kilátásai. Állattenyésztés és takarmányozás. 66. évfolyam, 4. szám. 276-299. o.

[18.] Siklósi Á. - Veress A. (2011): Pénzügyi számvitel II. A beszámolókészítés. Perfekt Gazdasági Tanácsadó, Oktató és Kiadó Zrt., Budapest, 387-396. o. file://C:/Users/USER/Downloads/024_II_11\%20P\%C3\%A9nz\%C3\%BCgyi\%20sz\%C3\%A1mvitel\%20II.\%20Besz.k\%C3\%A9sz..pdf Letöltés dátuma: 2018.10.01.

[19.] Siklósi Á. - Veress A. (2011): Könyvvezetés és beszámolókészítés. SALDO Pénzügyi Tanácsadó és Informatikai Zrt. Budapest. 459-466. o.

\section{Szerzők:}

\section{Dr. habil Fenyves Veronika}

Egyetemi docens, Tanszékvezető, oktatási dékánhelyettes

Debreceni Egyetem, Gazdaságtudományi kar

Számviteli és Pénzügyi Intézet, Kontrolling nem önálló Tanszék

fenyves.veronika@econ.unideb.hu

\section{Dr. habil Harangi-Rákos Mónika}

Adjunktus

Debreceni Egyetem, Gazdaságtudományi kar

Ágazati Gazdaságtan és Módszertani Intézet, Agrárközgazdasági nem önálló Tanszék rakos.monika@econ.unideb.hu

\section{Gergely Andrea}

Számvitel Msc

II. évfolyam

gergelyandrea0306@gmail.com 